\title{
POTENTIOMETRIC DETERMINATION OF GLYCOPYRRONIUM BROMIDE IN BINARY MIXTURE WITH INDACATEROL MALEATE USING POLYVINYL CHLORIDE (PVC) MEMBRANE, COATED GRAPHITE AND CARBON PASTE SENSORS
}

BY

Nasr Mohamed A. El-Abasawy, Ahmed A. Abouserie , Mohammed El Dosoky, Ayman Osman Elsayed*

\section{FROM}

Pharmaceutical Analytical Chemistry Department, Faculty of Pharmacy, Al-Azhar University, 11751 Nasr City, Cairo, Egypt.

\begin{abstract}
A novel approach was conducted in this article for the determination of glycopyrronium bromide (GLY) in binary mixture with indacaterol maleate using ion selective electrodes for its selective determination in pure form and pharmaceutical formulation. Four ion selective electrode sensors were designed for determination of glycopyrronium bromide namely; glycopyrronium bromide-polyvinyl chloride (GLYPVC) membrane, GLY-Coated graphite sensor and GLY-modified carbon paste sensors. The sensors are based on the ion association complexes of GLY cation with sodium tetra phenyl borate (GLY-TPB) and phosphomolybidic acid (GLY-PMA) counter anions as ion exchange sites using dioctylphthalate (DOP) as plasticizer. Validation of the method shows suitability of the proposed sensors for use in the quality control assessment of GLY and for its routine analysis. The results obtained were statistically compared to reported method and there was no significant difference between the proposed methods and the reported method regarding the accuracy and precision. The method was validated according to International Conference on Harmonization ( $\mathrm{ICH}$ ) guidelines and the results were satisfactory.
\end{abstract}

\section{Keywords}

Glycopyrronium bromide, Potentiometric determination, PVC membrane, coated graphite and carbon paste sensors

\section{Introduction}

Glycopyrronium bromide (GLY) is 3-(2-cyclopentyl-2-hydroxy-2phenylacetoxy)-1,1- dimethylpyrrolidinium bromide (Figure 1). It's a white, nonhygroscopic powder, freely soluble in water, soluble in methanol (96\%), very slightly soluble in methylene chloride (O'Neil, 2013). Ultibro ${ }^{\circledR}$ Breezhaler is a combination of indacaterol maleate and glycopyrronium bromide licensed as a maintenance bronchodilator treatment to treat chronic obstructive pulmonary disease in which indacaterol maleate is long acting $\beta_{2}$ agonist and glycopyrronium bromide is long acting antimuscarinic(Frampton, 2014). There is a few reported spectrophotometric method for simultaneous determination of indacaterol maleate and glycopyrronium bromide(Maha et al, 2016 \& Jaya et al, 2017) .Literature survey revealed that different methods for determination of glycopyrronium bromide in biological fluids using LC-MS (Matassa et al ,1992 \& Storme et al ,2008) HPLC (Venkateshwaran et al, 1995), GC (Murray et al,1984), visible spectrophotometric method (Ebeid et al, 1986 ). The objective of the 
present work is to design and prepare three ion selective electrodes, PVC, coated graphite and modified carbon paste sensors for determination of glycopyrronium bromide in bulk powder and pharmaceutical preparation.

The ion-selective electrode is defined as an electrode that is capable of generating a difference in electrical potential between itself and a reference electrode, the output potential is proportional to the amount or concentration of the selected ion in solution (Morf, 2012 \& Thomas, 2013).

The most widely used solid membrane electrodes are the plasticized poly vinyl chloride (PVC) electrodes which are based on the formation of ion-associates between drugs and counter ions, then the formed ion-associate was used together with PVC and a suitable plasticizer in preparation of the membrane electrode. On the other hand, liquid membranes are formed from immiscible liquids that selectively bond certain ions. The liquid ion-exchanger may be retained in a porous inert solid support, which separates the liquid electrode inner solution from the test solution (Moody et al, 1988 \& Ragab et al, 2015).

Coated graphite sensor, in which the membrane is cast onto solid-like graphite, can be used as long as the matrix of the membrane which does not react with the internal wire. In the classical coated graphite design, a conductor is directly coated with an appropriate ion selective polymer membrane usually poly (vinyl chloride), poly (vinyl benzyl chloride) or poly (acrylic acid) to form an electrode system that is sensitive to electrolyte concentrations. The advantage of using coated graphite sensor is that it can be used in small volume of sample, simple design (absence of internal solution), mechanical flexibility and the possibility of miniaturization and micro fabrication (Ammar et al , 2012).

Carbon paste electrodes are considered an important type of ion-selective electrodes not able for their ubiquitous properties that entail advantages over membrane electrodes such as chemical inertness, robustness, renewability, stable response, low ohmic resistance, no need for internal solution and suitability fora variety of sensing and detection applications.(Freiser H,1986 ; Solymanpour, 2015 \& Abu Shawish et al, 2013).

Moreover, carbon paste electrodes belong to nontoxic and environmentally friendly electrodes. In their case, problems with passivation are simply eliminated by a simple and quick renewal of their surface. The operational mechanism of the carbon paste electrodes depends on the properties of the modifier materials used to import selectivity towards the target species. ${ }^{(18)}$ Ion-selective electrodes have been extensively used in the determination of pharmaceutical compounds.( Kalcher et al, 1995 ; El Gohary et al, 2011 \& Abdel-Ghani, 2010). 


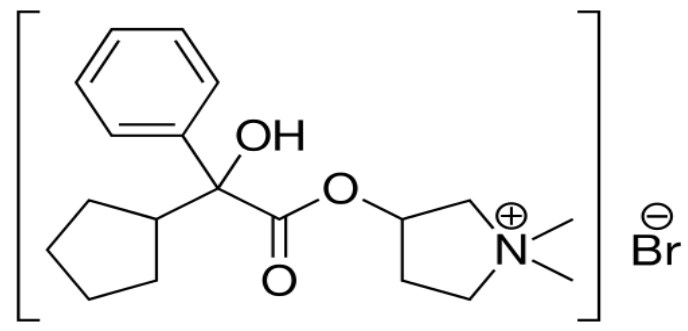

M. wt. : 398.34

M. formula: $\mathrm{C}_{19} \mathrm{H}_{28} \mathrm{BrNO}_{3}$

Figure (1): Structural formula of glycopyrronium bromide

\section{Experimental:}

\section{Instruments:}

Jenway pH meter 3510 (USA) with $\mathrm{Ag} / \mathrm{AgCl}$ reference electrode no 924017LO3-Q11C.

Bandelinsonorox, Rx 510 S, magnetic stirrer (Hungarian).

\section{Materials:}

\section{Pure samples:}

- Pure glycopyrronium bromide $(99.5 \%)$ was kindly supplied by Novartis Company, Egypt.

- Pure indacaterol maleate (99.7 \%) was kindly supplied by Novartis Company, Egypt.

\section{Pharmaceutical preparation:}

Ultibro ${ }^{\circledR}$ Breezhaler: each capsule claimed to contain $143 \mu \mathrm{g}$ indacaterol maleate and $63 \mu \mathrm{g}$ glycopyrronium bromide (B.No.S0308, manufactured by Novartis pharma stein, Switzerland), purchased from local market.

\section{Chemicals and reagents:}

All reagents used were of analytical grade and water used throughout the procedure was freshly distilled.

- Tetrahydrofuran, dioctylphthalate (DOP), poly vinyl chloride (PVC) of high relative molecular weight and graphite powder (synthetic 1-2 $\mu \mathrm{m}$ ), (Sigma Aldrich, Germany).

- Sodium tetraphenyl borate (Na TPB) and phosphomolybidic acid (PMA) (Sigma Aldrich- Germany) each prepared as $10^{-2} \mathrm{M}$ aqueous solution.

- Multi-wall carbon nanotubes powder (carbon >95.0\%, O.D. x L 6-9 nm x $5 \mu \mathrm{m}$ ) (Sigma-Aldrich, Germany).

- Glucose, glycine, sucrose, urea, calcium chloride, magnesium chloride, sodium chloride, potassium chloride and nickel chloride (El-Nasr Company, Egypt), prepared as $10^{-3} \mathrm{M}$ aqueous solution.

- Orthophosphoric acid prepared as 0.04 M aqueous solution (Prolabo, Paris, France). 
- Boric and acetic acids were prepared as 0.04 M aqueous solutions (Sigma-Aldrich, Germany).

- Sodium hydroxide prepared as 0.2 M aqueous solution (El-Nasr Company, Egypt).

- Britton Robinson (BR) buffer was prepared by mixing the acid mixture containing $0.04 \mathrm{M}$ phosphoric acid, $0.04 \mathrm{M}$ acetic acid and 0.04 M boric acid (Britton, 1931). Buffer solutions were adjusted with the appropriate amount of $0.2 \mathrm{M}$ sodium hydroxide to get the desired $\mathrm{pH}$.

\section{Standard solutions:}

A stock standard solution of glycopyrronium bromide $\left(10^{-2} \mathrm{M}\right)$ was prepared by dissolving $0.398 \mathrm{~g}$ of the drug powder in $50 \mathrm{~mL}$ of Britton Robinson buffer (BR) pH 5 and completed to $100 \mathrm{~mL}$ with the same solvent. Other solutions $\left(10^{-3}-10^{-6} \mathrm{M}\right)$ were prepared by serial dilution from the stock solution.

\section{Procedures:}

Preparation of the ion association complexes:

Ion -association complexes of glycopyrronium tetraphenylborate, (GLY-TPB) and glycopyrronium phosphomolybidate (GLY-PMA) were prepared by the addition of $150 \mathrm{~mL}$ of $1.0 \times 10^{-2} \mathrm{M}$ glycopyrronium solution to $150 \mathrm{ml}$ of $1.0 \times 10^{-2} \mathrm{M}$ of tetraphenyl borate (TPB) and $50 \mathrm{~mL}$ of phosphomolybidic acid (PMA), respectively. The resulting precipitates were left in contact with their mother liquor for $6 \mathrm{~h}$, then the precipitate was filtered and washed thoroughly with distilled water and left to dry at room temperature for $48 \mathrm{~h}$.

\section{Preparation of the sensors:}

\section{Preparation of glycopyrronium bromide PVC membrane sensor:}

In two separate glass petri dishes (5cm diameter), (198 $\mathrm{mg}$ of DOP was thoroughly mixed with $198 \mathrm{mg}$ of PVC and 4mg for GLY-TPB) and (195mg of DOP was thoroughly mixed with $195 \mathrm{mg}$ of PVC and $10 \mathrm{mg}$ for GLY-PMA). Each mixture was dissolved in $5 \mathrm{~mL}$ of tetrahydrofuran. Each petri dish was then covered with a Whatman No. 3 filter paper and left to stand overnight to allow for solvent evaporation at room temperature. A master membrane with a thickness of $0.1 \mathrm{~mm}$ was obtained. From the master membrane, $8 \mathrm{~mm}$ diameter disk was cut out from each prepared membrane and glued using tetrahydrofuran to a transposable PVC tip that was clipped into the end of the electrode glass part. The resulting electrode body was filled with equal portions of $10^{-2} \mathrm{M} \mathrm{KCl}$ and $10^{-2} \mathrm{M}$ glycopyrronium bromide. The prepared sensors were preconditioned by soaking in $10^{-2} \mathrm{M}$ drug solution. When not in use, the sensor was stored in air.

\section{Preparation of glycopyrronium bromide coated graphite sensor:}

In a glass petri dish (5-cm diameter), $190 \mathrm{mg}$ of DOP was thoroughly mixed with $190 \mathrm{mg}$ of PVC and $20 \mathrm{mg}$ of GLY-TPB. The mixture was dissolved in $5 \mathrm{ml}$ of tetrahydrofuran and homogenized thoroughly. The solvent was slowly evaporated at room temperature until oily concentrated mixture was obtained. One end of the commercial graphite bar $(2.5 \mathrm{~cm}$ length, $3 \mathrm{~mm}$ diameter $)$ was dipped in the electro active membrane mixture and the process was repeated several times until a layer of a proper thickness was formed covering the terminal end of graphite bar. The electrode was left standing at room temperature to dry. The other uncoated end of the graphite rod was sealed in a poly tetra ethylene tube, the tube was filled with metallic mercury into 
which a copper wire was dipped and used for connection. The prepared sensor was preconditioned by soaking in $10^{-2} \mathrm{M}$ drug solution for $6 \mathrm{~h}$. When not in use, the sensor was stored in air.

\section{Preparation of glycopyrronium bromide modified carbon paste sensor:}

In a mortar, $120 \mathrm{mg}$ of DOP was thoroughly mixed with $240 \mathrm{mg}$ of pure graphite powder, $30 \mathrm{mg}$ carbon nanotubes powder and $10 \mathrm{mg}$ of GLY-TPB.Then the carbon paste was carefully packed in a piston driven teflon holder $3 \mathrm{~mm}$ in diameter. The electrode surface regeneration was performed by screwing the piston and polishing with a wet smooth paper.

\section{Potential measurement conditions:}

- The electrochemical system can be represented as following:

- For glycopyrronium PVC membrane sensors: internal reference electrode/ internal filling solution/ PVC membrane/ test solution/ external reference electrode.

- For coated graphite sensor: reference electrode / test solution / graphite electrode.

- For modified carbon paste sensor: reference electrode / test solution / carbon paste electrode.

- $\mathrm{pH}$ range: 3-7 for PVC membrane sensors, coated graphite and modified carbon paste sensors.

- Soaking time: $24 \mathrm{~h}$ for PVC membrane sensors, $6 \mathrm{~h}$ for coated graphite sensor and zero time for modified carbon paste sensor.

- Response time: $15 \mathrm{~s}$ for PVC membrane sensors and $20 \mathrm{~s}$ for both coated graphite and modified carbon paste sensors.

\section{Sensors calibration:}

The prepared sensors, PVC, coated graphite and modified carbon paste sensors, were immersed in conjunction with $\mathrm{Ag} / \mathrm{AgCl}$ reference electrode in the solutions of glycopyrronium bromide in the range of $10^{-7}$ to $10^{-2} \mathrm{M}$. They were allowed to equilibrate while stirring until achieving constant reading of the $\mathrm{pH}$ meter. Then, the electromotive force values were recorded within $\pm 1 \mathrm{mV}$. Calibration graphs were plotted that relate the recorded electrode potential values to the negative logarithmic value of the molar drug concentrations.

\section{Validation of the procedure:}

The method was tested for linearity, range, limit of detection, acuracy, precision and specificity (ICH, 2005 ; IUPAC, 1976 \&Stefan , 1998).

\section{Procedure for pharmaceutical preparation:}

Contents of 25 Ultibro ${ }^{\circledR}$ capsules were weighed and mixed well. Amount of the powder equivalent to $0.996 \mathrm{mg}$ of glycopyrronium bromide was transferred into $25-\mathrm{mL}$ volumetric flask containing $20 \mathrm{ml}$ Britton Robinson (BR) buffer $\mathrm{pH}$ 5. The mixture was shaken vigorously for $15 \mathrm{~min}$ then sonicated for $20 \mathrm{~min}$ and filtered then completed to volume with the same buffer to obtain a solution labeled to contain $1.0 \times 10^{-4} \mathrm{M}$ of glycopyrronium bromide. 


\section{Reported method}

Simultaneous determination of indacaterol and glycopyrronium bromide using first order spectrophotometric method at 250 and $244 \mathrm{~nm}$ for indacaterol and glycopyrronium bromide respectively( Jaya et al, 2017).

\section{RESULTS \& DISCUSSIONS:}

Potentiometric methods are powerful and versatile analytical techniques that offer high sensitivity, accuracy, and precision as well as a large linear dynamic range, with relatively low-cost instrumentation (Morf, 2012 ).

In the present study three types of ion selective membrane electrodes, PVC, coated graphite and modified carbon paste sensors have been constructed for selective determination of glycopyrronium bromide. The methods are based on the fact that, glycopyrronium bromide behaves as a cation with an anionic type of ion exchanger such as tetraphehylborate and phosphomolybidic acid to prepare water insoluble association complexes using precipitation based technique. The resulting precipitates have low solubility product, suitable grain size and physically compatible with the matrix.

\section{Performance characteristics of the developed sensors:}

The electrochemical performance of the investigated sensors was evaluated according to IUPAC recommendation data (IUPAC, 1976) Calibrations were carried out by immersing the developed sensors in conjunction with $\mathrm{Ag} / \mathrm{AgCl}$ reference electrode in solutions of glycopyrronium bromide in the concentration range of $10^{-7}$ to $10^{-2} \mathrm{M}$. The potential displayed by the proposed sensors for constructive measurements of the standard drug solutions in the same day and from day to day did not vary by more than \pm $1 \mathrm{mV}$. Calibration slopes did not change by more than $\pm 1 \mathrm{mV} /$ decade concentration over a period of 4 weeks for PVC membrane sensor, 2 weeks for coated graphite sensor and 3 weeks for modified carbon paste sensor. The performance characteristics of the prepared sensors were summarized in table (1). 
Table (1): The performance characteristics of the proposed sensors for potentiometric determination of glycopyrronium bromide:

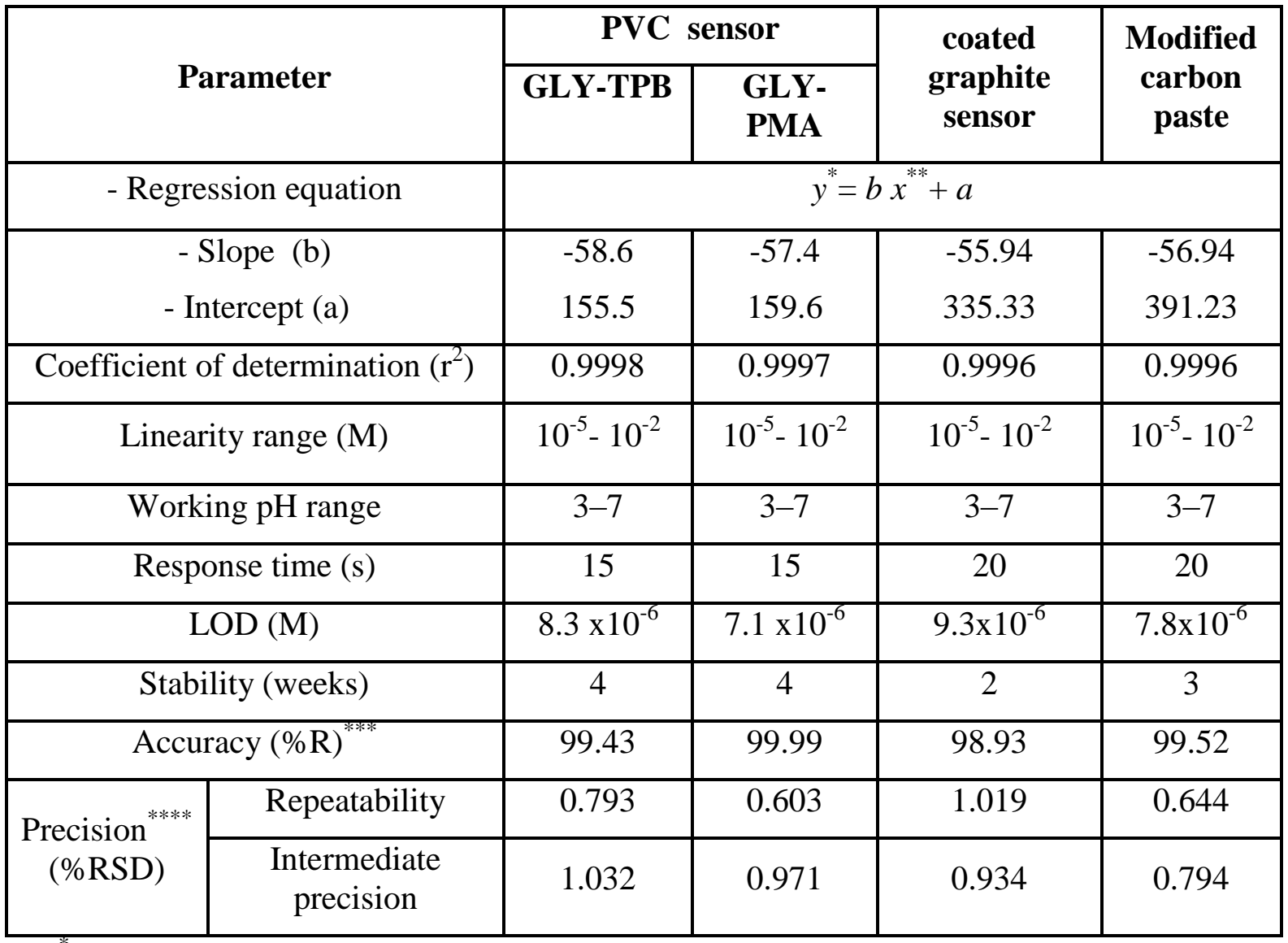

$y^{*}$ is the recorded sensor potential.

$x^{* *}$ is the -log molar concentration of the drug.

*** Average of nine determinations (three concentrations repeated three times).

**** $\%$ RSD of nine determinations (three concentrations repeated three times).

\section{Optimization of the method:}

(i) Effect of ion association complex percentage:

The ion association complexes are the most important part of ion selective sensors. It is the electro active ingredient, which is responsible for the selective recognition of the ion in the developed sensor.

- PVC mebrane sensors:

The main components of PVC membrane sensor are ion association complex, PVC and plasticizer (DOP). For the preparation of the membrane, the ion association complex, plasticizer and PVC should be taken in the appropriate percentage-weight ratios to improve the performance of the developed sensor. GLY-TPB and GLY-PMA were prepared and tested as a modifier for the proposed sensor. It was studied by varying the percentages of the ion association complex, while keeping the percentages of the PVC and the plasticizer equal 1:1 as shown in table (2). The best performance was obtained by 
using composition containing $198 \mathrm{mg}$ PVC and $4 \mathrm{mg}$ GLY-TPB ion pair with $198 \mathrm{mg}$ of DOP, and containing $195 \mathrm{mg}$ PVC and $10 \mathrm{mg}$ GLY-PMA ion pair with $195 \mathrm{mg}$ of DOP.

\section{- Coated graphite sensor:}

The ion association complex, GLY-TPB, was prepared and tested as a modifier for the proposed sensor. It was studied by varying the percentages of the ion association complex, while keeping the percentages of the PVC and the plasticizer equal 1:1 as shown in table (2). The best performance was obtained by using composition containing $190 \mathrm{mg}$ PVC and $20 \mathrm{mg}$ GLY-TPB ion pair with $190 \mathrm{mg}$ of DOP.

\section{- Modified carbon paste sensor:}

The ion association complex, GLY-TPB was used and tested by varying the amount of the ion exchange complex and other paste components as shown in table (2). The best performances were obtained by using composition containing $240 \mathrm{mg}$ graphite powder, $30 \mathrm{mg}$ carbon nanotubes powder and $10 \mathrm{mg}$ GLY-TPB ion pair with $120 \mathrm{mg}$ of DOP.

\section{(ii) Effect of soaking time:}

Freshly prepared sensors must be soaked to activate the surface of the membrane to form an infinitesimally thin gel layer at which ion exchange occurs. The investigated sensors were soaked in $10^{-2} \mathrm{M}$ solution of glycopyrronium bromide. Calibration graphs were constructed for the sensor after different time intervals $(0,3,6,9,12$ and $24 \mathrm{~h})$ till the slope of the calibration graph deviated largely from the Nernstian value and the sensor become out of use. The results indicated that the optimum soaking time was $24 \mathrm{~h}$ for PVC membrane sensors, $6 \mathrm{~h}$ for coated graphite and zero soaking time for modified carbon paste sensor as shown in table (3).

\section{(iii) Effect of pH:}

The effect of $\mathrm{pH}$ was investigated over a wide $\mathrm{pH}$ range $(2-8)$ to determine the working $\mathrm{pH}$ range of the proposed sensors. The investigations were performed using $10^{-3}$ and $10^{-4} \mathrm{M}$ of glycopyrronium bromide prepared in Britton Robinson buffer ( $\mathrm{pH} \mathrm{2-8).}$ The potential obtained at each $\mathrm{pH}$ value was recorded. Representative curves for the effect of $\mathrm{pH}$ on the proposed sensors are shown in Figures (2-5). For PVC membrane, coated graphite and modified carbon paste sensors the potential remained constant in the $\mathrm{pH}$ range of (3-7).

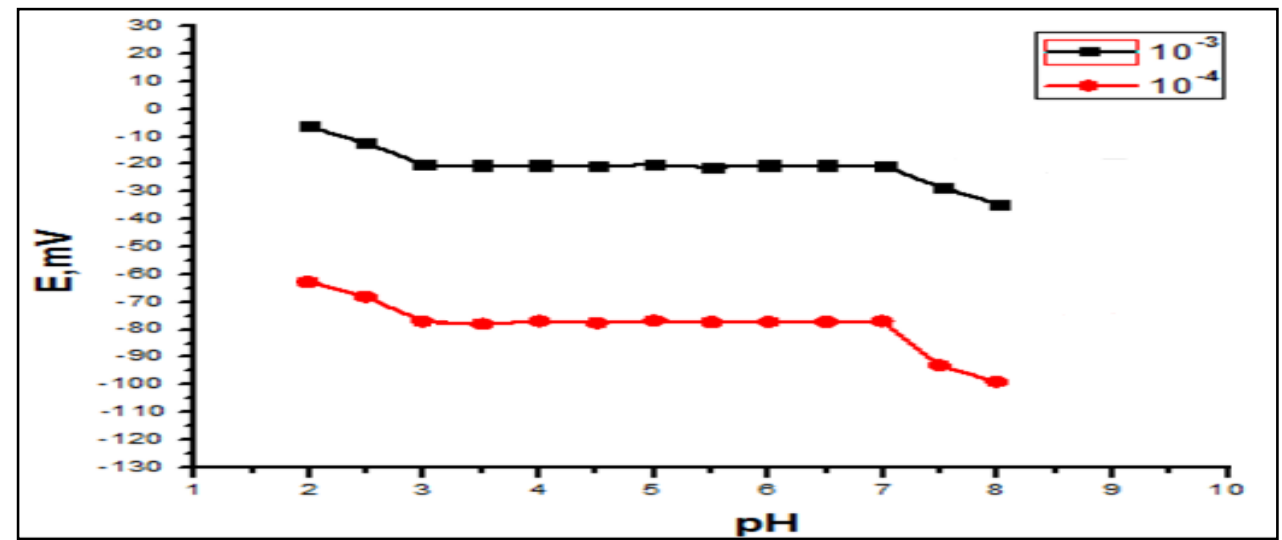

Figure (2): Effect of $\mathrm{pH}$ on the response of glycopyrronium bromide using PVC (GLY-TPB) membrane sensor. 


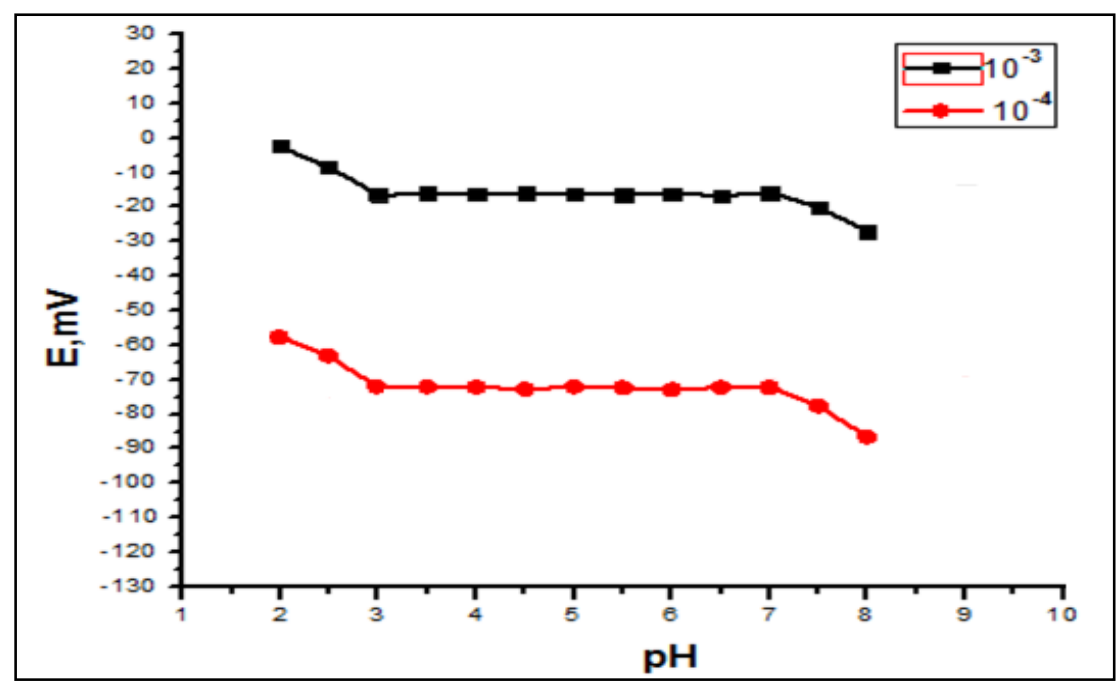

Figure (3): Effect of pH on the response of glycopyrronium bromide using PVC (GLY-PMA) membrane sensor.

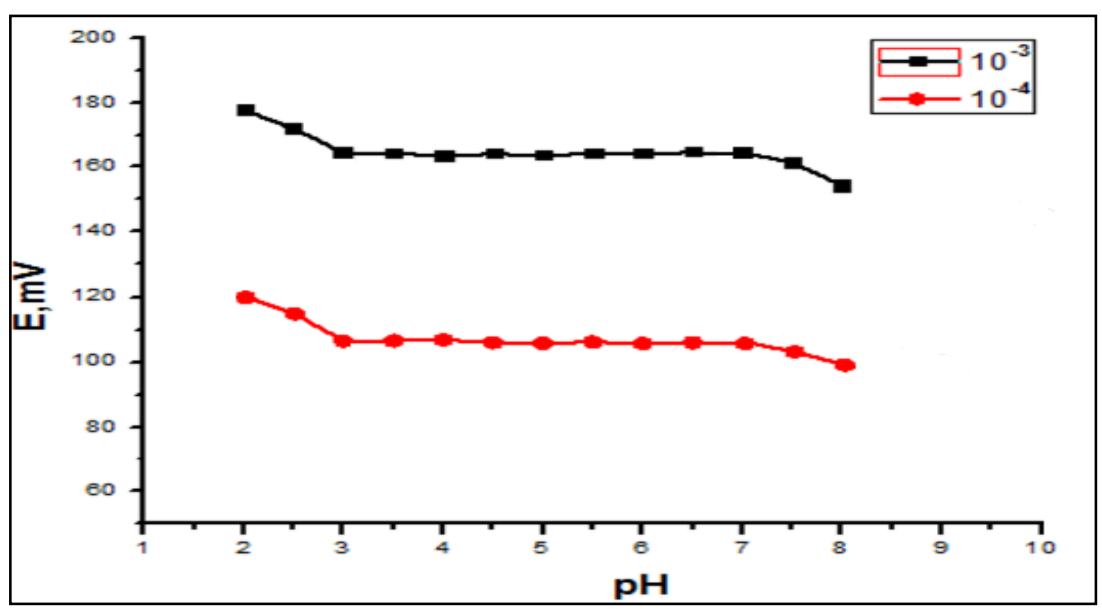

Figure (4): Effect of pH on the response of glycopyrronium bromide using coated graphite sensor.

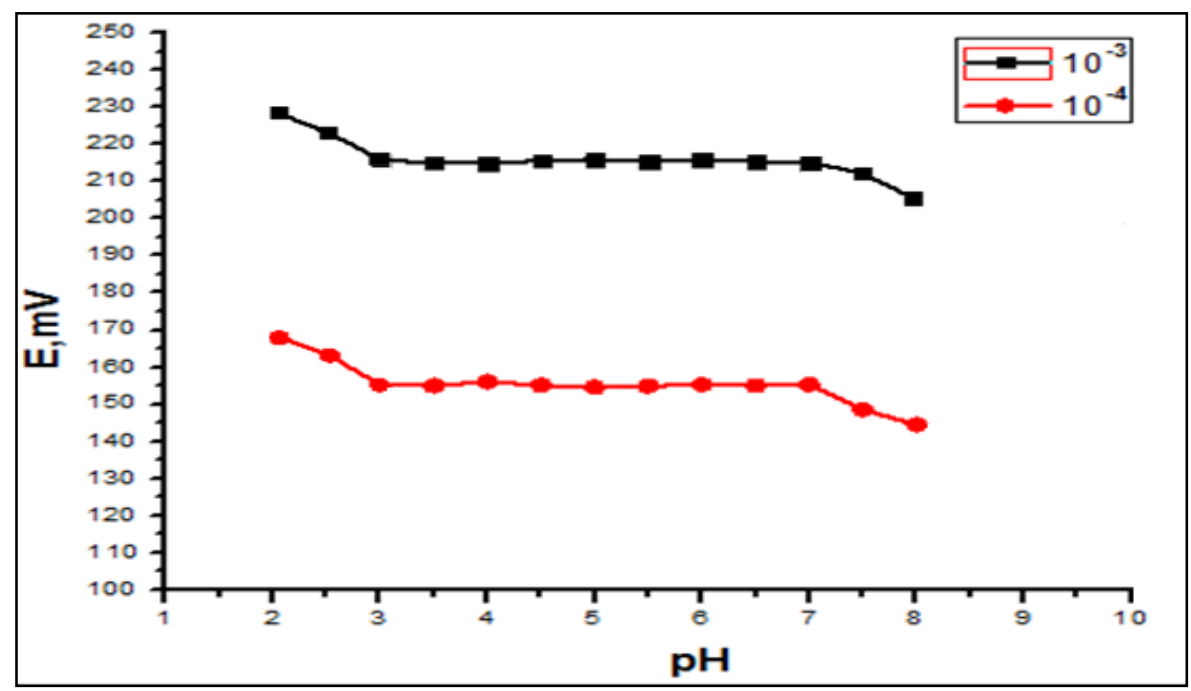

Figure (5): Effect of pH on the response of glycopyrronium bromide using modified carbon paste sensor. 


\section{(iv) Sensors selectivity:}

The influence of the related interfering compounds on the response of the investigated sensors towards the drug was investigated. The separate solution method (SSM) was applied when determining the selectivity coefficient for inorganic cationsbased on measuring the potential of $10^{-3} \mathrm{M}$ solution of the drug and the interfering ions separately. Then the selectivity coefficients $\log K_{\text {Durg, }}^{\text {pot }}{ }^{+z}$ Were calculated

by applying the following equation(Bakker et al, 2000).

$$
\log K_{\text {Durg }_{J} J^{+z}}^{\text {pot }}=\frac{E_{2}-E_{1}}{S}+\log [\mathrm{drug}]-\log \left[J^{+z}\right]^{\frac{1}{z}}
$$

Where $E_{1}$ and $E_{2}$ are the electrode potential of $10^{-3} \mathrm{M}$ solution of each of investigated drug and interferent ion $\left[J^{+z}\right]$, respectively, and $\mathrm{S}$ is the slope of calibration curve.For neutral molecules, such as glucose, urea and sucrose the selectivity coefficient $\log K_{\text {Durg }^{+}{ }^{+z}}^{\text {pot }}$ was calculated using the matched potential method [MPM]

(Bassell et al, 1965 \& Baumann, 1968). This method does not depend on the NicolskyEisenman equation at all, in this method; the selectivity coefficient is defined as the activity ratio of primary and interfering ions that give the same potential change under identical conditions. At first, a known activity ( $\left.\mathrm{aA}^{\prime}\right)$ of the primary ion solution is added into a reference solution that contains a fixed activity (aA) of primary ions and the corresponding potential change $(\Delta \mathrm{E})$ is recorded. Next, a solution of an interfering ion is added to the reference solution until the same potential change $(\Delta \mathrm{E})$ is recorded, where $(\mathrm{aB})$ is the activity of the interfering ion that produced the same potential change $(\Delta \mathrm{E})$. The change in potential produced at the constant background of the primary ion must be the same in both cases. $K^{\text {POT }}=\left(\mathrm{aA}^{\prime}-a A\right) / a B$. The potentiometric selectivity coefficients were then calculated. The interfering compounds were; potassium chloride, calcium chloride, magnesium chloride, sodium chloride, nickel chloride, glucose, urea, glycine and sucrose.

The results of the calculated selectivity coefficients indicated that the proposed sensors were highly selective towards the studied drugs as shown in table (4).

\section{(v) Response time of the proposed sensors:}

For analytical applications, the response time of the prepared sensors is of critical importance. The average time required for the electrode to reach a steady potential response within $\pm 1 \mathrm{mV}$ of the final equilibrium value after successive immersion of a series of the drug solutions, each having a 10-fold difference in concentration, was investigated. Stable responses were achieved within $15 \mathrm{~s}$ for PVC membrane sensor and $20 \mathrm{~s}$ for both coated graphite and modified carbon paste sensors. 


\section{Method validation:}

- Linearity and range:

Under the described experimental conditions, the calibration graph for each sensor was constructed by plotting the recorded sensor potential versus negative logarithmic value of the molar drug concentration.

The regression plots were found to be linear over the range of $10^{-5}-10^{-2} \mathrm{M}$ for the studied drug, as shown in figures (6-8).

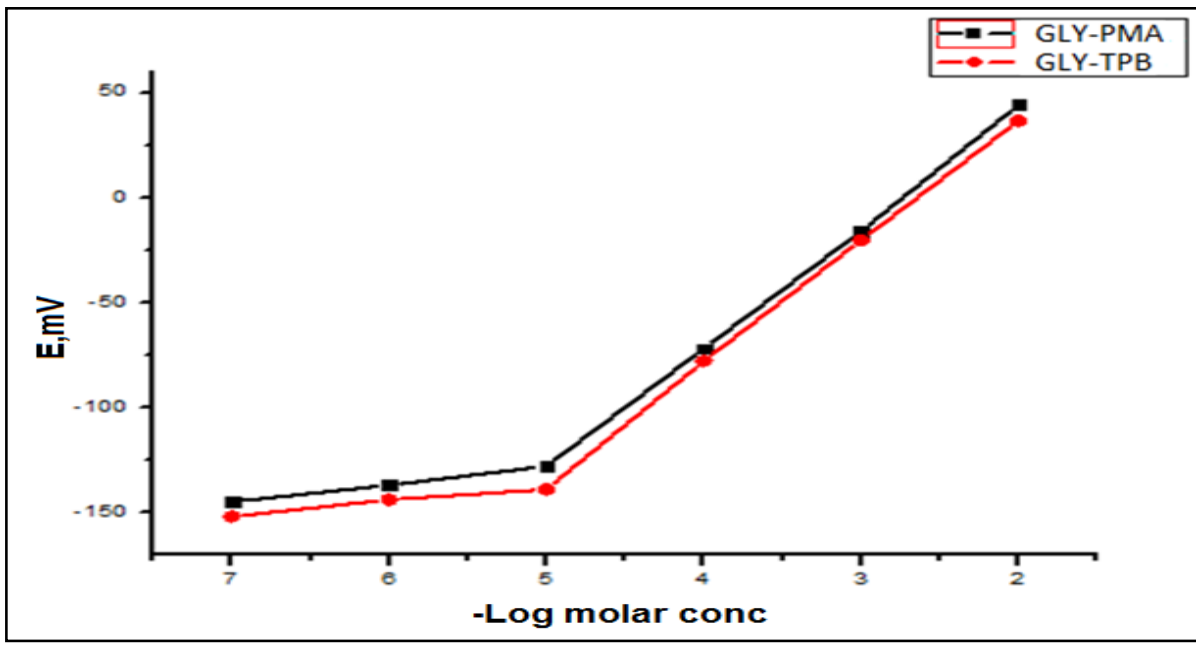

Figure (6): Profile of the potential in $\mathrm{mV} /-\mathrm{Log}$ molar concentration of glycopyrronium bromide using PVC membrane sensors.

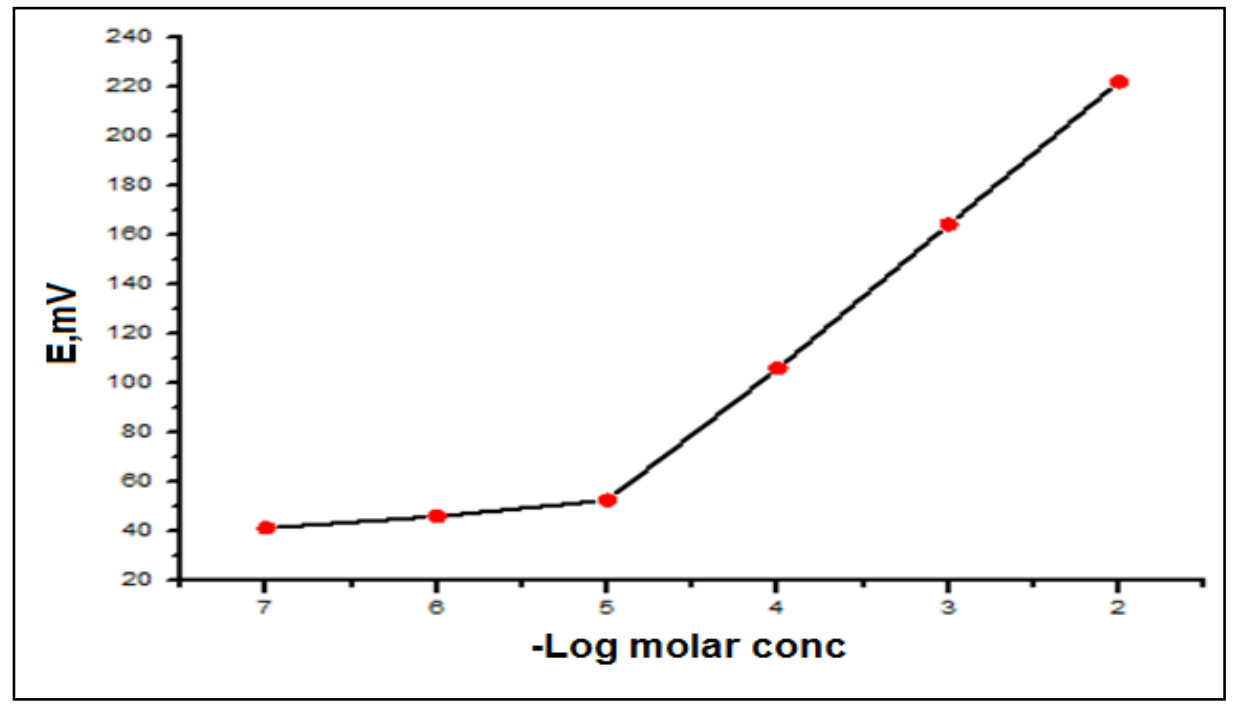

Figure (7): Profile of the potential in $\mathrm{mV} /-$ Log molar concentration of glycopyrronium bromide using coated graphite sensor. 


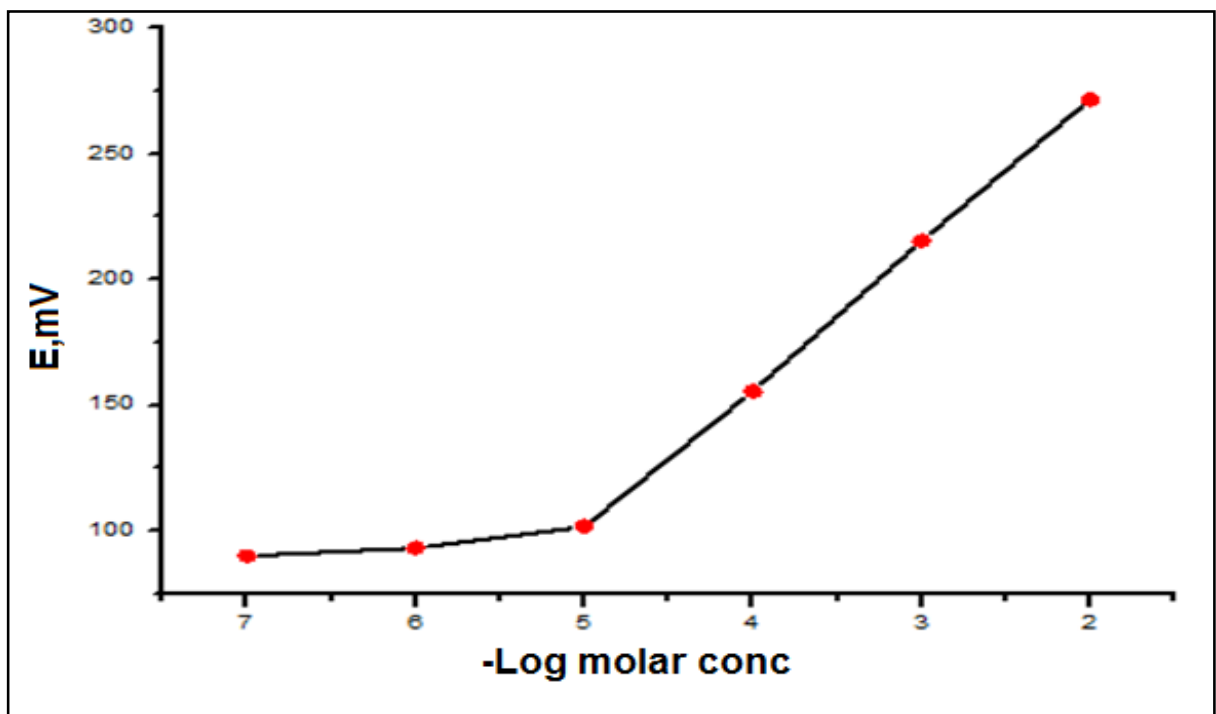

Figure (8): Profile of the potential in $\mathrm{mV} /-$ Log molar concentration of glycopyrronium

bromide using modified carbon paste sensor.

\section{- Limit of detection:}

Limit of detection was measured by interception of the extrapolated arms of figures (6-8). It was found to be $8.3 \times 10^{-6}$ for PVC (GLY-TPB) membrane sensor,7.1 $\times 10^{-6}$ for PVC (GLY-PMA) membrane sensor, $9.3 \times 10^{-6}$ for coated graphite sensor and $7.8 \times 10^{-6} \mathrm{M}$ for modified carbon paste sensor. The small values of LOD indicate good sensitivity of the described sensors

\section{- Accuracy and precision:}

Accuracy of the described method, calculated as the mean percent recovery $(\% \mathrm{R})$, was assessed by applying the described procedure for triplicate determination of three concentration levels covering the linearity range of each drug $\left(10^{-4}, 10^{-3}\right.$ and $10^{-2}$ M). The results in table (1) indicate the accuracy of the proposed method.

Precision of the method, calculated as the percent relative standard deviation (\%RSD), was assessed by triplicate determination of three concentration levels covering the linearity range of each drug $\left(10^{-4}, 10^{-3}\right.$ and $\left.10^{-2} \mathrm{M}\right)$ within one day for repeatability and on three successive days for intermediate precision. The small values of \%RSD indicated high precision of the method as shown in table (1).

\section{- Specificity:}

Synthetic mixtures containing different ratios of the two drugs were prepared and mixed well. Then, the mixtures were analyzed using the prepared sensors. More over the results of the calculated selectivity coefficients indicated that the proposed sensors were highly selective towards the studied drug, table (4). 


\section{Pharmaceutical application:}

The proposed sensors were applied for the selective determination of glycopyrronium bromide in binary mixture with indacaterol in Ultibro ${ }^{\circledR}$ capsules. Satisfactory results were obtained in good agreement with the label claim, indicating no interference from excipients and additives. The obtained results were statistically compared to those obtained by the reported method. (Jaya et al, 2017). No significant differences were found by applying t-test and F-test at 95\% confidence level,(Armitage,1994) indicating good accuracy and precision of the proposed method, as shown in table (5).

Table (2): Optimization of the membrane composition (w/w \%) of the proposed sensors:

\begin{tabular}{|c|c|c|c|c|c|c|}
\hline & \multicolumn{3}{|c|}{ Composition \% (w/w) } & \multirow{2}{*}{$\begin{array}{c}\text { Linearity rang } \\
\text { (M) }\end{array}$} & \multirow{2}{*}{$\begin{array}{c}\text { Slope } \\
\text { (mV/decade) }\end{array}$} & \multirow{2}{*}{$\mathbf{r}^{2}$} \\
\hline & Ion & PVC & DOP & & & \\
\hline \multirow{4}{*}{ 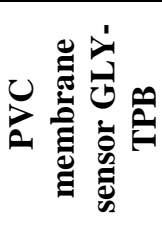 } & 0.5 & 49.75 & 49.75 & $1 \times 10^{-5}-1 \times 10^{-2}$ & -54.03 & 0.9993 \\
\hline & 1 & 49.5 & 49.5 & $1 \times 10^{-5}-1 \times 10^{-2}$ & -58.6 & 0.9998 \\
\hline & 2 & 49 & 49 & $1 \times 10^{-5}-1 \times 10^{-2}$ & -56.22 & 0.9995 \\
\hline & 3 & 48.5 & 48.5 & $1 \times 10^{-5}-1 \times 10^{-2}$ & -55.17 & 0.9994 \\
\hline \multirow{4}{*}{ } & 1.5 & 49.25 & 49.25 & $1 \times 10^{-5}-1 \times 10^{-2}$ & -56.13 & 0.9995 \\
\hline & 2.5 & 48.75 & 48.75 & $1 \times 10^{-5}-1 \times 10^{-2}$ & $\begin{array}{c}-57.4 \\
\end{array}$ & 0.9997 \\
\hline & 3.5 & 48.25 & 48.25 & $1 \times 10^{-5}-1 \times 10^{-2}$ & -56.22 & 0.9994 \\
\hline & 4.5 & 47.75 & 47.75 & $1 \times 10^{-5}-1 \times 10^{-2}$ & -54.40 & 0.9994 \\
\hline \multirow{6}{*}{ 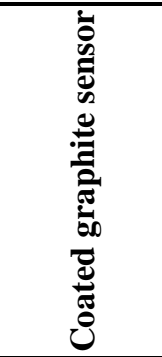 } & \multicolumn{3}{|c|}{ Composition \% (w/w) } & \multirow{2}{*}{$\begin{array}{c}\text { Linearity rang } \\
\text { (M) }\end{array}$} & \multirow{2}{*}{$\begin{array}{c}\text { Slope } \\
\text { (mV/decade) }\end{array}$} & \multirow{2}{*}{$\mathbf{r}^{2}$} \\
\hline & GLY-TPB & $\begin{array}{l}\text { PVC } \\
\end{array}$ & DOP & & & \\
\hline & 3 & 48.5 & 48.5 & $1 \times 10^{-5}-1 \times 10^{-2}$ & -54.61 & 0.9994 \\
\hline & 5 & 47.5 & 47.5 & $1 \times 10^{-5}-1 \times 10^{-2}$ & -55.94 & 0.9996 \\
\hline & 7 & 46.5 & 46.5 & $1 \times 10^{-5}-1 \times 10^{-2}$ & -55.11 & 0.9996 \\
\hline & 9 & 45.5 & 45.5 & $1 \times 10^{-5}-1 \times 10^{-2}$ & -53.91 & 0.9994 \\
\hline \multirow{6}{*}{ 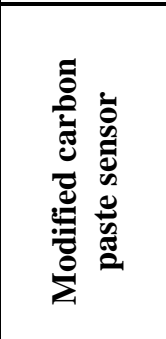 } & \multicolumn{3}{|c|}{ Composition \% (w/w) } & \multirow{2}{*}{$\begin{array}{c}\text { Linearity rang } \\
\text { (M) }\end{array}$} & \multirow{2}{*}{$\begin{array}{c}\text { Slope } \\
\text { (mV/decade) }\end{array}$} & \multirow{2}{*}{$\mathbf{r}^{2}$} \\
\hline & GLY-TPB & Graphite & DOP & & & \\
\hline & 1.5 & 60.6 & 30.3 & $1 \times 10-5-1 \times 10-2$ & -53.47 & 0.9993 \\
\hline & 2.5 & 60 & 30 & $1 \times 10-5-1 \times 10-2$ & -56.94 & 0.9996 \\
\hline & 3.5 & 59.3 & 29.6 & $1 \times 10-5-1 \times 10-2$ & -55.17 & 0.9996 \\
\hline & 4.5 & 58.6 & 29.3 & $1 \times 10-5-1 \times 10-2$ & -54.27 & 0.9995 \\
\hline
\end{tabular}


Table (3): Effect of soaking time on the described sensors:

\begin{tabular}{|c|c|c|c|c|}
\hline \multirow{2}{*}{$\begin{array}{c}\text { Soaking } \\
\text { time/h }\end{array}$} & \multicolumn{4}{|c|}{ Slope (mV/decade) } \\
\cline { 2 - 4 } & \multicolumn{2}{|c|}{ PVC sensor } & Coated graphite & $\begin{array}{c}\text { Modified carbon } \\
\text { sensor } \\
\text { paste sensor }\end{array}$ \\
\cline { 2 - 4 } & GLY-TPB & GLY-PMA & -48.85 & $-\mathbf{5 6 . 9 4}$ \\
\hline 0 & -52.6 & -51.8 & -51.58 & -52.22 \\
\hline 3 & -53.7 & -53.1 & -55.94 & -51.17 \\
\hline 6 & -54.5 & -53.8 & -53.93 & -48.95 \\
\hline 9 & -56.1 & -55.07 & -52.78 & -42.10 \\
\hline 12 & -57.4 & -56.33 & -52.12 & -40.77 \\
\hline 24 & $\mathbf{- 5 8 . 6}$ & $\mathbf{- 5 7 . 4}$ & & \\
\hline
\end{tabular}

Table (4): Selectivity coefficients of the described sensors:

\begin{tabular}{|c|c|c|c|c|}
\hline \multirow{3}{*}{ Interferent* } & \multicolumn{4}{|c|}{$\log K$} \\
\hline & \multicolumn{2}{|c|}{ PVC membrane sensor } & \multirow{2}{*}{$\begin{array}{c}\text { Coated graphite } \\
\text { sensor }\end{array}$} & \multirow{2}{*}{$\begin{array}{c}\text { Modified } \\
\text { carbon paste } \\
\text { sensor }\end{array}$} \\
\hline & GLY-TPB & GLY-PMA & & \\
\hline $\begin{array}{c}\text { Indacaterol } \\
\text { maleate }\end{array}$ & -2.53 & -2.90 & -3.51 & -2.83 \\
\hline KCl & -3.31 & -2.95 & -2.52 & -3.44 \\
\hline $\mathrm{CaCl}_{2}$ & -2.88 & -3.46 & -3.15 & -3.21 \\
\hline $\mathbf{M g C l}_{2}$ & -2.42 & -3.64 & -2.87 & -2.65 \\
\hline $\mathrm{NaCl}$ & -2.85 & -3.22 & -2.74 & -2.62 \\
\hline $\mathrm{NiCl}_{2} \cdot 6 \mathrm{H}_{2} \mathrm{O}$ & -3.43 & -3.35 & -3.32 & -3.23 \\
\hline Glucose & -3.57 & -2.53 & -3.37 & -2.96 \\
\hline Urea & -2.94 & -3.42 & -2.64 & -2.46 \\
\hline Glycine & -3.37 & -3.25 & -3.52 & -3.49 \\
\hline Sucrose & -3.66 & -2.95 & -3.11 & -3.09 \\
\hline
\end{tabular}

"all interferent are in the concentration of $1 \times 10^{-3} \mathrm{~mol} \mathrm{~L}^{-1}$ 
Table (5): Determination of glycopyrronium bromide in Ultibro ${ }^{\circledR}$ capsules by the described sensors and reported method:

\begin{tabular}{|c|c|c|c|c|c|}
\hline \multirow{2}{*}{ Parameters } & \multicolumn{2}{|c|}{ PVC membrane sensor } & \multirow{2}{*}{$\begin{array}{c}\text { Coated } \\
\text { graphite sensor }\end{array}$} & \multirow{2}{*}{$\begin{array}{l}\text { Modified } \\
\text { carbon } \\
\text { paste } \\
\text { sensor }\end{array}$} & \multirow{2}{*}{$\begin{array}{c}\text { Reported } \\
\text { method } \\
\text { (Jaya et al } \\
\text { 2017) }\end{array}$} \\
\hline & GLY-TPB & GLY-PMA & & & \\
\hline $\mathrm{n}^{*}$ & 5 & 5 & 5 & 5 & 5 \\
\hline $\begin{array}{c}\text { Average } \\
\text { (\%Recovery) }\end{array}$ & 99.84 & 100.21 & 99.68 & 99.84 & 99.92 \\
\hline$\% \mathrm{RSD}$ & 0.578 & 0.674 & 0.520 & 0.790 & 1.069 \\
\hline Variance & 0.333 & 0.457 & 0.268 & 0.622 & 1.141 \\
\hline $\begin{array}{c}t \text { value } \\
(2.306)^{* *}\end{array}$ & 0.143 & 0.519 & 0.444 & 0.125 & - \\
\hline $\begin{array}{l}\text { F value } \\
(6.388)^{* *}\end{array}$ & 3.426 & 2.496 & 4.257 & 1.834 & - \\
\hline
\end{tabular}

Number of experiments.

** The values in parenthesis are tabulated values of " $t$ "and " $F$ " at $(\mathrm{P}=0.05)$.

\section{Conclusion}

A novel approach was conducted for determination of glycopyrronium bromide (GLY) in binary mixture with indacaterol maleate using ion selective electrodes for its selective determination in pure form and pharmaceutical formulation, The sensors are based on the ion association complexes of GLY cation with sodium tetra phenyl borate (GLY-TPB) and phosphomolybidic acid (GLY-PMA) counter anions as ion exchange sites using dioctylphthalate (DOP) as plasticizer. The designed sensors seem to give better results of detection limit, dynamic range and higher selectivity. In addition, coated graphite sensor has simple design and can be applied in small volume of sample. Validation of the method shows suitability of the proposed sensors for use in the quality control assessment of GLY and for its routine analysis.

\section{REFERENCES}

Abdel-Ghani NT, Hussein SH. (2010) Determination of diphenylpyraline hydrochloride in pure solutions and pharmaceutical preparations using ion selective electrodes under batch and FIA conditions. Anal Lett.; 43(4):582-602. 
Abu Shawish HM, Ab Ghalwa N, saadeh SM , El Harazeem H. (2013) Development of novel potentiometric sensors for determination of tartrazine dye concentration in foodstuff products. Food Chem.;138(1):126-132.

Abu Shawish HM, Dalou AA, Ab Ghalwa N, Kharnish GI, Hammad J , Basheer AH. (2013) Determination of pethidine hydrochloride using potentiometric coated graphite and carbon paste electrodes. Drug Test Analysis. 2013; 5(4):213-222.

Ammar RA, Otaif H, Al-Warthan A. (2012) A novel ion-selective membrane electrode for the determination of duloxetine. Anal Methods.; 4(5):1427-31.

Armitage P, Berry G. (1994) Statistical methods in medical research. 3rd ed. Oxford (UK): Blackwell;:1254-1259.

Bakker E, Pretsch E, Bühlmann P. (2000) Selectivity of potentiometric ion sensors. Anal Chem.; 72(6):1127-33.

Bassell J, Denny RC, Jeffrey JM, Textbook of Quantitative Inorganic Analysis, 4th edition.1965;1441-1443.

Baumann EW. (1968) Trace fluoride determination with specific ion electrode. Anal Chim Acta; (42):127-132.

Britton HTS, Robinson RA, Universal buffer solutions and the dissociation constant of veronal. J Chem Soc. 1931; 1456-1462.

Ebeid, M. Y., Moussa, B. A., \& Malak, A. A. A. (1986) Analysis of some antispasmodic drugs: oxyphencyclimine and glycopyrronium bromide. Pharmaceutisch Weekblad, , 8, 252-258.

El Gohary NA, El Nashar RM, Aboul-Enien HY. (2011) Potentiometric determination of sibutramine using batch and flow injection analysis. Anal Lett.; 44 (1-3):241-57.

Frampton, J. E.(2014) QVA149 (indacaterol/glycopyrronium fixed-dose combination): review of its use in patients with chronic obstructive pulmonary disease. Drugs, , 74(4), 465-488.

Freiser H. (1986) Coated wire ion-selective electrodes. Principles and practice. J Chem Soci.; 82(4):1217-21.

International Conference on Harmonization, ICH Harmonised Tripartite Guideline. (2005) Validation of analytical procedure: text and methodology, Q2 (R1). Geneva: International Conference on Harmonization;;965-969.

International union of pure and applied chemistry, (1976) Analytical chemistry division, commission in Analytical nomenclature, Pure App. Chemistry.; 48:127-132.

Jaya D., Dhara P., Khushboo P., Dhananjay M. (2017) Development and validation of first-order derivative spectrophotometry for simultaneous determination of indacaterol maleate and glycopyrronium bromide in pharmaceutical dosage form. International Journal of Research in Pharmacy and Biosciences.; 4(3):1218. 
Kalcher K, Kauffmann JM, Wang J, Svancara I, Vytras K, Neuhold C, Yang Z. (1995) Sensors Based on Carbon Paste. Electranal.; 7(1):5-22.

Maha F. Abdel Ghany, Lobna A. Hussein, Nancy Magdy,Hend Z. Yamani,.(2016) Simultaneous spectrophotometric determination of indacaterol and glycopyrronium in a newly approved pharmaceutical formulation using different signal processing techniques of ratio spectra,2016, doi: 10.1016/j.saa..01.002.

Matassa, L. C., Woodard, D., Leavitt, R. K., Firby, P., Beaumier, P..(1992) Solid phase extraction techniques for the determination of glycopyrrolate [glycopyrronium bromide] from equine urine by liquid chromatography tandem mass spectrometry and gas chromatography mass spectrometry. Journal of Chromatography: Biomedical Applications, ,111, 43-48.

Moody G, Saad B, Thomas J. (1988) The development of polymer matrix membranes for ion-selective electrodes. Sel Electrode Rev.; 10:71.

Morf WE. The principles of ion-selective electrodes and of membrane transport. Amsterdam: Elsevier; 2012.698-706.

Murray, G. R., Calvey, T. N., Williams, N. E., \& Chan, K.. (1984) Quantitative capillary column gas chromatographic method for the determination of glycopyrronium in human plasma. Journal of Chromatography B: Biomedical Sciences and Applications, ,308, 143-151.

O'Neil, M. J. (Ed.).(2013) The Merck index: an encyclopedia of chemicals, drugs,biologicals( $15^{\text {th }}$ ed.).Cambridge, UK: RSC Publishing..

Ragab MT, El-Rahman MKA, Ramadan NK, El-Ragehy NA, El-Zeany BA.(2015) Novel potentiometric application for the determination of pantoprazole sodium and itopride hydrochloride in their pure and combined dosage form. Talanta.; 138:28-35.

Solymanpour A, Ghasemian M.(2015) Chemically modified carbon paste sensor for the potentiometric determination of carvedilol in pharmaceutical and biological media. Measurement.; 59:14-20.

Stefan RI, Aboul-Enein HY.(1998) Validation criteria for developing ion-selective membrane electrodes for analysis of pharmaceuticals. Accredit Qual Assur.; 3(5):194-6.

Storme, M. L., t'Kindt, R. S., Goeteyn, W., Reyntjens, K., \& Van Bocxlaer, J. F. (2008) Quantitative determination of glycopyrrolate in human plasma by liquid chromatography electrospray ionization mass spectrometry: The use of a volatile ion-pairing agent during both liquid-liquid extraction and liquid chromatography. Journal of Chromatography B, , 876, 24-30.

Thomas JDR. (2013) Ion-selective electrode reviews. Amsterdam: Elsevier;

Venkateshwaran, T. G., King, D. T., \& Stewart, J. T.(1995) HPLC determination of ondansetron-atropine and ondansetron-glycopyrrolate mixtures in $0.9 \%$ sodium chloride injection. Journal of Liquid Chromatography \& Related Technologies, , 18, 2647-2659. 


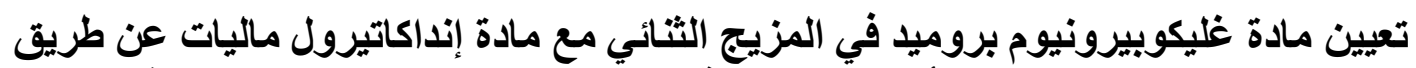

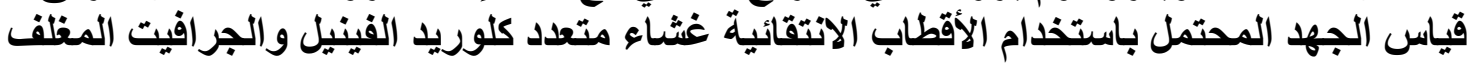
ومعجن الكربون

\section{للسادة الاكاترة}

نصر محمد علي العبساوي، احمد عبد الحليم أبو سريع محمد، محمد محمد احمد الدسوقي، ايمن عثمان السيد * عنمان

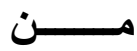

قسم الكيمياء التحليلية الصيدلية، كلية الصيدلة، جامعة الأزهر ، مدينة نصر، القاهرة ـمصر.

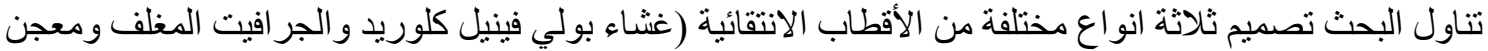

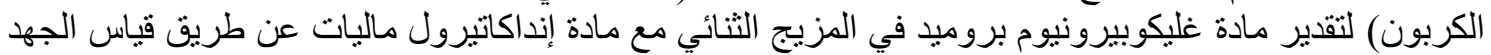

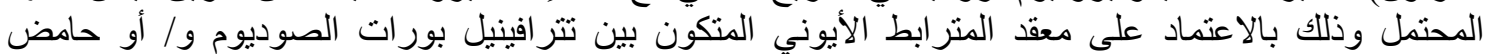

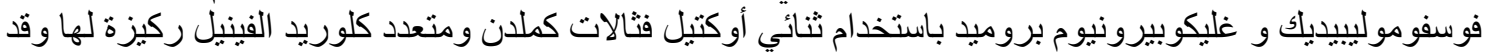

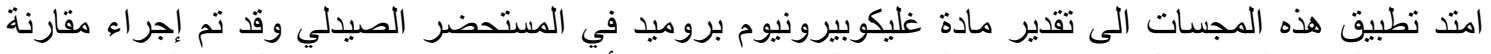

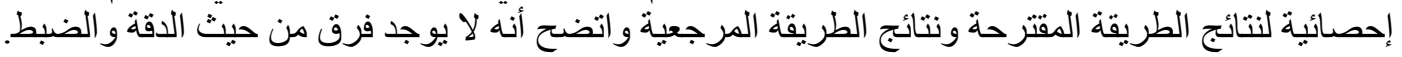

